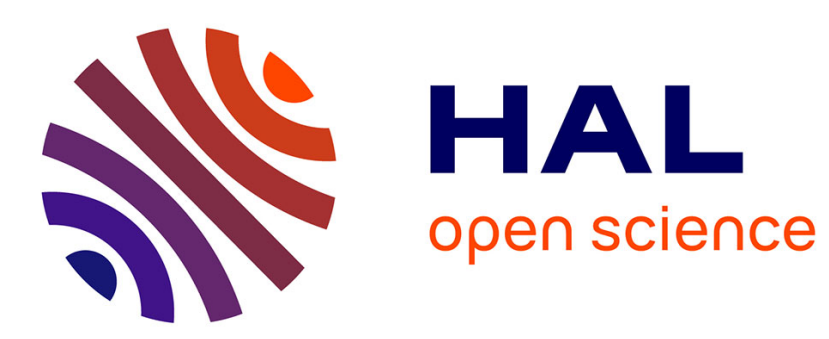

\title{
The familiar faces of political renewal at City Hall
}

Timothy Whitton

\section{To cite this version:}

Timothy Whitton. The familiar faces of political renewal at City Hall. Observatoire de la société britannique, 2012, La nouvelle donne politique en Grande-Bretagne (2010-2012), 12, pp.97-113. 10.4000/osb.1317 . hal-01923780

\section{HAL Id: hal-01923780 \\ https://hal.science/hal-01923780}

Submitted on 5 Dec 2018

HAL is a multi-disciplinary open access archive for the deposit and dissemination of scientific research documents, whether they are published or not. The documents may come from teaching and research institutions in France or abroad, or from public or private research centers.
L'archive ouverte pluridisciplinaire HAL, est destinée au dépôt et à la diffusion de documents scientifiques de niveau recherche, publiés ou non, émanant des établissements d'enseignement et de recherche français ou étrangers, des laboratoires publics ou privés. 


\title{
The familiar faces of political renewal at City Hall
}

\author{
Timothy Whitton
}

\begin{abstract}
On September 24th, 2010 Ken Livingstone was chosen as the Labour Party's candidate to attempt to become the new mayor of London in 2012. His first words emphasized the fact that unlike the mayoral election in 2000 when he asked Londoners to choose between an Old Labour and New Labour vision of the capital city, this time round, getting rid of the conservative mayor, Boris Johnson, would be an important step in rejecting the cuts that David Cameron and George Osborne are inflicting on the public services. The aim of this contribution is to examine the way in which Ken Livingstone became mayor of London and how he intends to challenge Boris Johnson in order to conquer City Hall once again in 2012.
\end{abstract}

Key words: Greater London Authority, Livingstone, Johnson, Ken, Boris, mayor, congestion charge, City Hall, coalition. 


\section{Introduction}

On 3 May 2012 the fourth Greater London Authority (GLA) elections will be held in London to choose the 25 members of the capital city's assembly and above all, its executive mayor. In 2000, Ken Livingstone became London's first directly elected mayor after defying his own party, New Labour, which had rigged the selection process to prevent him from standing and stealing the limelight from their own candidate. Londoners preferred Livingstone's independent, maverick style and above all his desire to put the interests of London first rather than those of a national political party.

His first mandate saw him introduce the congestion charge which guaranteed the success he would need to be re-elected in 2004, all the more so as no other political party could find a suitable candidate to oppose him, especially on his own turf where personality politics had become more important than manifestos. Meanwhile, New Labour pulled every string in order to reintegrate him into the party so that he would defend their colours in this second election. The possibility of London being awarded the Olympic Games was looming large and both local and central government knew full well that they had to cooperate more openly in order to reassure the International Olympic Committee.

Despite his second electoral success, Livingstone's connivance with New Labour had somewhat reduced his grass-root London support and accusations of cronyism adroitly exploited by the press gradually eroded his popularity. The Conservatives had also come up with their own candidate capable of challenging the incumbent mayor in the field of personality politics. Boris Johnson did exactly that, won the 2008 elections and gave David Cameron the political stronghold he needed in London to bolster his national appeal.

In 2000, Livingstone had played the card of political independence and in 2004, that of burying the hatchet so that the GLA and central government should see the Olympic Games through together. In 2008, his opponent managed to underline the fact that it was perhaps Time for a Change and once elected, pursued many of the policies that Livingstone had initiated ${ }^{1}$. For the 2012 election Livingstone has seemingly reverted to a 2000 style campaign by clearly stating that one of the London

\footnotetext{
1 This was Johnson's 2008 campaign slogan invented by the Australian political strategist, Lynton Crosby, drafted in by the Conservative Party in order to organise their candidate's campaign.
} 
mayor's main tasks will be to oppose central government's policies and above all the spending cuts being inflicted on public services. This openly belligerent attitude possibly stems from the fact that the 2012 election will not be won or lost according to any major GLA policy issue, all the more so since the Olympic Games seem to be going to plan. In light of this, the familiar faces of those who seek election in 2012 will have their work cut out to give their respective campaigns the twist enabling their particular brand name to stand out from the others. Failing this, and if there is no major Olympic hitch, a second Johnson victory could be a foregone conclusion.

\section{0: David against Goliath}

Livingstone's victory in the first mayoral election can essentially be put down to his ability to portray himself as being the candidate for London and Londoners rather than a party apparatchik inclined to promote his party's politics rather than strategies in keeping with local policies $^{2}$. This attitude was to cost him his membership of the Labour Party because he disagreed with the Public Private Partnership (PPP) they wanted to set up in order to renovate the London underground. Livingstone bitterly opposed this choice saying that it would bury relationships between London government and the private companies involved in reams of intricate contracts that armies of lawyers would have to unravel at the slightest snarl. Ideologically speaking, Livingstone believed that the London underground should be managed by Londoners themselves through their local government which tallied with his - as yet secret - plan to create a popular shareholding system to finance renovation work.

Yet the PPP had been written into the Labour Party's 1997 election manifesto which Livingstone was supposed to support given that he had fought and won his seat as a Labour candidate ${ }^{3}$. It had also been included in the White Paper A Mayor and Assembly for London: the

\footnotetext{
2 The first lines of Livingstone's 2000 election manifesto state this very clearly: “...The direct election of a Mayor and Assembly for London will give Londoners back the right to govern their own affairs and decide upon their own priorities. I am standing as an independent candidate because I believe the job of the Mayor will be to stand up for London. If candidates and policies can be imposed centrally then devolution will mean nothing. (emphasis added).

3 Labour plans a new public/private partnership to improve the Underground, safeguard its commitment to the public interest and guarantee value for money to taxpayers and passengers. Labour Party manifesto 1997, New Labour because Britain deserves better.
} 
Government's Proposals for Modernising the Governance of London'. Despite the intense pressure brought upon him, Livingstone refused obstinately to support the PPP for the underground contending that the Party's General Election manifesto was one thing and the manifesto for London another. At this stage, it is worth wondering whether Livingstone was not being deliberately provocative in order to reap full benefit from being the (future) victim of the Party's political machinery ${ }^{5}$.

As was to be expected, Livingstone fell foul of the Labour Party which used a particularly devious primary election system to make sure that their own candidate, Frank Dobson, would be elected ${ }^{6}$. The press went to town ${ }^{7}$ over these rigged elections and a short time later, on March 6th, Livingstone announced his intention to run as an independent candidate:

"I am standing as an independent solely in order to ensure that we have real devolution to London. I will not be setting up a new political party and I still hope one day to be able to return to the Labour Party".

Thus the "purple bus" campaign kicked off and Livingstone was duly excluded from the party for a period of five years". But Londoners appreciated his style, they were fond of "our Ken" as they would refer to him and were quite ready to punish New Labour politicians for excluding the local hero from being their official candidate, but also for their overall arrogant attitude towards government.

\footnotetext{
${ }^{4}$ Cm. 3897, the Stationery Office, London, 1998.

${ }^{5}$ See for example "London Mayor : citizen Ken sends Millbank's plans down the tube ; Labour's shortlist scheme in turmoil after former GLC leader refuses to toe the party line over privatisation of underground", The Independent, 17/11/1999.

6 The electoral college established to select the official candidate was divided into three parts and heavily weighted in favour of those most likely to support the New Labour project to the detriment of the rank and file. See Whitton, T., Ken "le Rouge" et la Mairie de Londres, du Greater London Council à la Greater London Authority, l'Harmattan, 2010, p. 61-68.

7 See for example, "Labours mayoral candidate: the vanquished Livingstone listens for the voices of London to tell him to turn again and stand as mayor", "Labour faces biggest split since 1980s after 'tainted' Dobson win", The Independent, 21/02/2000 \& "Defeated Livingstone cries foul", The Times, 21/02/2012.

8 'I will run for mayor; exclusive. 'Red' Ken announces he will defy Blair and stand as an independent", The Evening Standard, 06/03/2000.

9 For their deliberately provocative and outlandish campaign, Livingstone's team purchased a Routemaster bus, painted it purple and roamed the streets of London. Livingstone spoke to Londoners via a megaphone and one of the messages on the bus asked Londoners to "Hoot4Ken".
} 
Try as they might, New Labour couldn't manage to sway opinion and on May $4^{\text {th }} 2000$, Ken Livingstone became the first directly elected executive mayor of London, streaks ahead of the Conservative candidate, Steve Norris, Dobson coming in a sorry fourth behind the Liberal Democrats' candidate ${ }^{10}$. Livingstone had won thanks to his maverick stance, his deliberately provocative campaign but above all by convincing Londoners that it was up to them to choose between the political juggernaut of central government and the defender of local policies. This first victory was going to give him the opportunity to show that his political acts were in keeping with his promises ${ }^{11}$.

\section{4: the congestion charge victory}

Officially, Livingstone was initially excluded from the Labour Party for a period of five years and on taking office, he immediately expressed his intention to challenge the decision to use a PPP in order to renovate the London underground. As if to reinforce this desire to impose what he considered to be the needs of London, he also declared his plan to introduce the congestion charge, a tax levied on vehicles entering the central part of London. This was enshrined in section 295 of the 1999 Greater London Authority Act which under the heading "Road User Charging" states that:

a) Transport for London,

b) any London borough council, or

c) the Common Council ${ }^{12}$, may establish or operate schemes for imposing charges in respect of the keeping or use of motor vehicles on roads in its area.

The charge was to become effective on February $17^{\text {th }} 2003$ during the school holidays so as to reduce traffic during the first days of operation and while the private company, Capita, began setting up the complex system of cameras to be used in order to enforce it, Livingstone continued to fight the PPP plan tooth and nail. But he knew full well that the success of the congestion charge depended largely on an improved public transport system given that the basic aim was to coax commuters out of their cars and onto the buses, trains and of course the underground. In view of this, opposition to the PPP

\footnotetext{
${ }^{10}$ Full details of the results can be found in Whitton T., op. cit., p. 202.

${ }^{11}$ Livingstone's first words on being elected were "As I was saying before I was so rudely interrupted fourteen years ago...".

12 I.e. the GLA.
} 
gradually dwindled even when the reintegration of Livingstone into the Labour Party was refused by the party's National Executive Council on July $24^{\text {th }}, 2002^{13}$.

On January $26^{\text {th }}, 2003$ an underground accident at Chancery Lane sparked off a bout of fierce opposition to Livingstone's congestion charge and he was asked to postpone it so that car traffic could for a while ease the extra burden on public transport. The mayor's answer was a categorical "no" given the financial penalties that the GLA would suffer from such a delay. Alone in the face of adversity, Livingstone weathered the storm and as the official opening of the charge grew nearer, braced himself to deal with the national and international media knowing full well that his political future was inextricably linked to the success of this major project. As it happened, very few of the problems that his opponents had brandished actually materialised and in spite of a few colourful anti congestion charge demonstrations and some minor technical hitches, the charge was a relative success ${ }^{14}$. At the end of April during his monthly press conference, the Prime Minister warmly congratulated the mayor of London for such an innovative policy, quite in keeping with New Labour's modern vision of politics, and prepared public opinion for the reintegration of Livingstone ${ }^{15}$. This was to take some months given that the party already had an official candidate, Nicky Gavron, but it was common knowledge that she had little chance either against Livingstone, if he chose to run as an independent again, or the other party candidates. On January $7^{\text {th }}, 2004$ the ban on Livingstone was officially lifted and as provocative as ever, he declared that both Blair and Thatcher, two of the most dominant figures in recent political history had tried to crush him and both had failed.

Livingstone's victory in the June $10^{\text {th }}, 2004$ election was less resounding than in 2000. This can surely be put down to his recent collaboration with New Labour who suffered during the local elections held on the same day. Yet both parties knew that they had more to gain

\footnotetext{
13 Ironically, the decision was taken on the very same day as City Hall, which houses the GLA, was being inaugurated by the Queen.

14 Perhaps the most famous anti congestion charge demonstration was organised by Terry Burrows, window cleaner by trade - and Guinness Book World Record holder who to protest about the substantial increase in his overheads that the congestion charge would imply on a daily basis, drove into central London on a horse drawn carriage. These vehicles are exempt from the charge to allow the Queen and the Lord Mayor to circulate freely.

15 “"Livingstone right on car fees', says Blair", The Daily Telegraph, 28/04/2003.
} 
together than by constantly being at loggerheads especially with the Olympic agenda looming so large.

\section{The second mandate: Livingstone losing touch}

There is no denying that along with the success of the congestion charge, the Olympic Games provided a serious backdrop for the 2004 mayoral elections. Yet when on July $5^{\text {th }}, 2005$ Jacques Rogge announced that they had been awarded to London, the decision came perhaps too early for the mayor to reap electoral success from a project that was bound to substantially modify the capital. To this end, Livingstone had openly admitted on various occasions that his interest in sport was limited but that the Games would enable the GLA to renovate and improve huge swathes of east London.

When a few hours following the announcement London was hit by several bomb attacks, Livingstone managed to reach a peak of popularity by stating in statesmanlike terms that the terrorists had failed in their attempt to weaken Londoners faith in their city ${ }^{16}$. But despite carrying the banner of "London United", his second mandate was to lack a major project that would continue to promote his particular brand name. Instead, Livingstone became bogged down in a series of statements about the cost of the Games that affected his already tainted credibility concerning the financial governance of the capital. At the same time, scandals and sleaze were gradually whittling away at his popular support and reinforcing the belief that he was turning London into what the popular press coined a "kenocracy"17. Public opinion had already been shocked when he had welcomed the Muslim preacher, Sheikh Yusuf al-Qaradawi to City Hall a year earlier and the Finegold affair had weakened his support within the Jewish community ${ }^{18}$. The mayor's grand projects including a new toll bridge across the Thames,

\footnotetext{
16 http:/ / www.youtube.com/watch?v=6BSIBPsbL9c

17 This was described by The Evening Standard as "the fanatically loyal group of advisers who worked for Mr Livingstone long before he became Mayor and who imposed his will on City Hall”, 04/08/2008 in “ 'Ken's cronies', f1.6m PAYOFF; (1) Former Mayor's eight aides benefit from his rule change (2) Boris settles rather than waste taxes on long court battle (2) EXCLUSIVE (4) Merry-go-round of excess".

18 On February 8th, 2005, Livingstone had publicly compared Olivier Finegold, a journalist with Jewish origins, to a concentration camp guard. Livingstone had subsequently refused to apologise for his declarations and become embroiled in a complex court case to determine whether he was still fit for public office.
} 
CrossRail ${ }^{19}$, hosting the first stage of the Tour de France or a system of bicycle rental like the Parisian "vélib" model were proving to be insufficient to maintain his popularity and prevent him from becoming "Blair's mayor". In the same vein, Londoners were beginning to tire somewhat from his outbursts on issues that had very little to do with his job of mayor ${ }^{20}$. In May, 2006 when the Venezuelan president Hugo Chavez paid a well publicised visit to his socialist friend Livingstone in what became known as the "brooms for oil" deal", the mayor was criticised for lording it over London especially when the western extension of the congestion charge was introduced despite popular disagreement clearly shown in the surveys ${ }^{22}$.

The reason behind Livingstone's provocative behaviour even towards his traditionally faithful electorate can perhaps be explained by the lack of a credible challenger. This can be compounded by the fact that in the previous elections, the Liberal Democrat candidates, respectively Susan Kramer in 2000 and Simon Hughes in 2004, had failed to make any serious inroads into the main candidates' electorate despite hopes that they might just make it to the top two and then benefit from a considerable second preference vote count ${ }^{23}$. In this way, Brian Paddick, their candidate for the 2008 election, tried desperately to portray himself as the "third" man, an alternative not only to the two main candidates but also to the two main parties.

\footnotetext{
19 CrossRail is a colossal project to create a fast train line across London linking Maidenhead in the west to Shenfield in the east.

20 Livingstone constantly criticised George Bush, Ariel Sharon and certain Saudi Arabian leaders. He had also insulted the American ambassador in London for failing to pay the congestion charge as well as the Reuben brothers, two Jewish businessmen involved in the construction of the Olympic village.

${ }^{21}$ London was to receive cheap oil from Venezuela in exchange for its expertise on urban government provided by the GLA.

22 "Where the streets are paved with gold. On Monday the London congestion-charge zone will double in size, while on Tuesday an anti-road-pricing petition of more than 1.5 million signatures will close on the Number 10 website. Dr Leon Mannings considers the connection", The Daily Telegraph (London issue), 17/02/2007.

23 The supplementary vote system is used to choose the mayor of London. Voters express a first choice and if they choose, a second choice. After the first round, if no candidate has received $50 \%$ of first choice votes, a second round is organised for the top two candidates. Voters whose first choice has been eliminated but whose second choice is one of the top two candidates have their second preference vote added to the first-round totals for the leading candidates.
} 
Meanwhile, the Conservatives had looked somewhat frantically for a suitable candidate ${ }^{24}$ but it was only in July 2007, having postponed their deadline for candidates to declare, that they turned to Boris Johnson. At this stage they felt that the least their Have I Got News For $Y o u^{25}$ candidate could do would be to compete with Livingstone in the popularity ratings. London had certainly changed since Livingstone had become mayor in 2000, but the 2008 elections were definitely going to be a battle of personalities rather than programmes. In view of this, the relentless anti-Livingstone campaign organised by the Evening Standard cannot be overlooked especially when the incumbent and his campaign team became embroiled in sleaze and accusations of corruption in the last six months before the election ${ }^{26}$. While Livingstone had to face allegations of corruption, the Conservatives handed their candidate's campaign over to Lynton Crosby, the Australian political strategist. His scheme to wrest City Hall from Livingstone was based on what he called the "doughnut" strategy whereby the incumbent mayor was portrayed as being an essentially "zone-one" candidate: canvassing for the conservative candidate had therefore to be concentrated in the outer more Conservative-voting boroughs ${ }^{27}$. This time round, the mayoral election was to be fought along more traditional party lines linked to personality politics:

Tory canvassers found 'very, very wide' recognition of their candidate. You only had to say on the doorstep, 'I'm campaigning for Boris', and people would know what you were talking about. Boris got people talking about politics, a subject which self-respecting Londoners often prefer to ignore. He and Ken were demonstrating that to get people to come out and vote, you needed interesting candidates on the ballot paper, not tedious party clones. ${ }^{28}$

Johnson's most convincing argument was surely Time for a Change which had quickly become his official slogan. After eight years of Livingstone's reign over London the electorate were prepared to give

\footnotetext{
${ }^{24}$ See Whitton T., "Over to you Mr Johnson: the defeat of Ken Livingstone in 2008", in Whitton T., directeur de publication, Londres: capitale internationale, multiculturelle et olympique, revue $\mathrm{n}^{\circ} 11$, Observatoire de la Civilisation Britannique, décembre 2011, p.

25 A popular chat show where contestants were required to improvise in order to comment on current affairs. Both Livingstone and Johnson were regularly invited to attend and sometimes to chair contests.

26 Ibidem.

${ }^{27}$ Ibid.

${ }^{28}$ Gimson, A., Boris. The Rise of Boris Johnson, Simon \& Schuster, 2008, p. 284.
} 
the helm of the city to another personality capable of reinforcing the reputation of London as an international capital. This they did in May 2008 not so much as to reject Livingstone as to usher in some political renewal at City Hall. As was to be expected, Brian Paddick came in third after the first count with an even lower score than his predecessors but this can be put down to 2008 having been polarised around the two main characters whose highly mediatised duel was undeniably behind the $10 \%$ increase in voter participation. This said, four years later confrontation will more than likely concern the same people whose task it will be to convince the electorate that despite their familiar faces, they do represent political renewal.

\section{From red Ken to Boris blue}

Johnson's administration got off to a difficult start with the resignation of a senior advisor, James McGrath, after remarks he was said to have made publicly about Caribbean immigrants. This was followed at the beginning of July by the departure of deputy mayor Ray Lewis for allegations of sleaze. Lewis' resignation came as a serious blow to Johnson's momentum given his plans to fight youth crime especially what had been labelled "knife" crime - which was to be his deputy's special remit. On August $19^{\text {th }}$ it was the turn of Tim Parker, Chief Executive (First Deputy Mayor) of the GLA to tender his resignation because of strained relations with other staff members. Yet, despite these setbacks which smacked of Livingstone's last six months in power, it was on August $24^{\text {th }}$ when Johnson was given the Olympic flag to wave six times in order to officially acknowledge the handover ceremony in Beijing, that the success of his first mandate was inextricably linked to the successful organisation of the 2012 Games: Boris Johnson had shed the mantle of celebrity to don that of statesman $^{29}$. To this end, when Brian Coleman, one of the senior Conservative members of the GLA, accused British athletes present in Beijing of being "tainted" with blood over China's human rights records, his remarks brought not only the assembly but also his party into disrepute. Whichever "big idea" mayor Johnson might come up with after 2008, there was no avoiding the fact that for the next four years, London was going to be first and foremost an international Olympic city. In this respect, the electorate would be particularly

${ }^{29}$ For all this Johnson was remembered in the press for his flag waving as a "character created in a unique collaboration between JK Rowling and the Beano". See "BBC coverage needed Boris bombing into the Olympic pool", The Independent, 01/08/2011. 
sensitive to issues concerning the Olympic legacy despite the fact that "London won the Games in a time of economic plenty but [was] building them in a global recession" 30 .

Nevertheless Londoners had not elected a merely Olympic mayor and it quickly became apparent that many of the bedrock policies ${ }^{31}$ promoted during the 2008 campaign would be rolled out against an economic landscape that few had anticipated. Price rises in London transport, announced in September and implemented in January 2009 put an end to Johnson's political honeymoon at the GLA and turned his response to the overall downturn in the British economy into an issue itself. The economic crisis was indeed forcing Johnson to frame many of his policy choices as correctives rather than innovative choices for the capital, including counter-cyclical investment to boost overall recovery. But at the same time, the economy was the area where he would use his powerbase to fire the occasional broadside against Cameron and the Conservative Party who in the run up to the General Elections were being particularly careful about not doing too many favours for the rich. Concerning the 50p tax rate that Alistair Darling was to impose on people earning more than $£_{1} 150000$ a year and which neither David Cameron nor the Shadow Chancellor George Osborne had said they would scrap once in power, Johnson declared:

I just feel that as Mayor of London, I have to point out that London is full of fantastically creative businesses that need to attract the best talent from around the world. If you tell them you are going to take considerably more of their money away than they could expect in the competitor capitals, that's a poke in the eye for London. ${ }^{32}$

His performance on October $5^{\text {th }}$ at the Conservative conference was equally provocative as he stole the show from the party's top politicians by explaining that what he could do in London, could be done

\footnotetext{
30 "Is the economic downturn going to blight the 2012 London Olympics? The big question", The Independent, 16/01/2009.

${ }^{31}$ Housing, crime, youth and transport for example.

32 "All eyes on Boris as he calculates his future; Boris Johnson has made enough waves as the Mayor of London to be considered as an heir to David Cameron [- but will he make the jump? Interview by Andy McSmith", The Independent, 27/04/2009. Johnson renewed his criticism on Labour's tax strategy in January 2010 when bankers' bonuses were targeted. See "Financial: tax attack, Johnson under fire", The Guardian, 16/01/2010.
} 
nationwide by the next - Conservative - government ${ }^{33}$. Johnson has always been suspected of nurturing the hope of leading his party and occupying Downing Street ${ }^{34}$ but the coalition that emerged from the 2010 General Elections was not in keeping with his vision of power, especially in its shared form.

\section{Ken versus the coalition: political renewal at the GLA?}

The famous "doughnut" strategy organised by Lynton Crosby in 2008 had repeated itself in the London constituencies in 2010 and shown that Labour would need a candidate capable of reaching across these boundaries if it wanted to conquer mayoral power once again. Oona King was convinced that she could accomplish just this and soon after the General Elections started her bid to become Labour's official candidate. Her gender, ethnicity and youth certainly enabled her to stand out from Livingstone, the maverick warhorse of the London left whose critics claimed he had become too tired and obdurate to organise a serious rematch against Johnson. His supporters, on the contrary, were wary of Labour choosing an inexperienced candidate such as King for London while the party itself was in the difficult throes of selecting its own leader. The capital's mayor holds the biggest mandate of any politician in Britain and at this stage in the reorganisation of the party, putting the right people in the right places was vital. While King felt she could muster a higher proportion of the swing and suburb voters than Livingstone, those who had rallied behind Johnson in 2008, Livingstone was certainly the candidate who was quite openly basing his campaign on an anti-Tory and anti-cuts platform. His first words uttered in Croydon - one of the outer boroughs incidentally - on June $1^{\text {st }}$ to launch his bid clearly stated his campaign pitch: "I want to be Mayor for one overriding reason: if I am elected my focus will be to do everything I can to protect Londoners from the recession and the effects of the Government's policies",35.

\footnotetext{
33 "Conference Sketch; Boris devises his own plot, with a climax at No 10. After a cameo on EastEnders, the Mayor of London steals the show at the conference", The Daily Telegraph, 06/10/2012.

34 "Weekend: Next stop, Number 10?: Boris Johnson talks adultery, ambitions and why he's a 'monstrous zeppelin of self-confidence' with Simon Hattenstone", The Guardian, 16/04/2011.

35 This also figures clearly on his "KenforLondon" website: http://www.kenlivingstone.com/about
} 
On September 11 $1^{\text {th }}, 2010$ Johnson officially announced he would be seeking a second term as mayor of London fully aware that his main rival would persuade Londoners to make him carry the can for central government spending cuts: “I welcome Boris Johnson's confirmation that he will run again because he now has a record that means he can be held to account. [...] The Government's cuts are his cuts" ${ }^{\prime 36}$. To make his case, time and again Livingstone would return to the hefty hikes in the cost of public transport that had been implemented since Johnson had come to power, while constantly reminding the electorate of the mayor's political affiliation ${ }^{37}$. This aggressive stance was perhaps the main reason for his being elected - once again - to the party's NEC in September and it certainly proved that one of Livingstone's main skills was to garner the support of those who had initially given up on him, people who believed that in high profile elections such as the mayoral election in 2008, the loser loses all. In this particular contest, what tipped the balance to give him a distinct advantage over King was the need for Labour to have a candidate capable not only of being mayor, but first and foremost of beating Johnson and then standing up to Cameron and Osborne. In short, despite King's other advantages, Livingstone came across as having an acute understanding of the levers of power that would have to be pushed and pulled in order to find a suitable alternative to the coalition's agenda.

Indeed, Livingstone's first words on learning that he had won the competition to become the Labour Party's candidate ${ }^{38}$ were once again to underline his commitment to oppose central government's cuts and help Labour defeat the coalition:

The London election in 2012 is their [Londoners'] chance to send a message to Cameron and Osborne that we don't want these devastating cuts to our public services, fewer jobs and declining living standards. We will stand up for London and to do that we need to change the mayor. If you want to get them out, we start by getting out Boris Johnson. ${ }^{39}$

Ever since, Livingstone's political message has remained fairly faithful to this line of action, for he realises that to win back the

\footnotetext{
36 "Boris sets his sights on race to be Olympics mayor", The Times, 11/09/2010.

${ }^{37}$ See for example "Who's best for London?", The Guardian, 09/09/2012.

${ }^{38}$ Livingstone received $68,6 \%$ of the vote to King's 31,4\%.

39 http://www.telegraph.co.uk/news/newsvideo/uk-politics-video/8022467/KenLivingstone-is-Labours-London-Mayoral-candidate.html accessed 01/09/2011.
} 
mayoralty in 2012, he will have to take the message into Johnson's own camp beyond the boundaries of the inner London boroughs where his traditional supporters are concentrated.

\section{Conclusion}

The loss of City Hall in May 2012 would seriously undermine Cameron's attempts to woo Londoners with his particular brand of modern, metropolitan conservatism. He might enjoy the sight of his arch rival being humiliated but his joy will be short for at this time, a period of midterm "blues" will have set in for the coalition government especially if the spending cuts have begun to bite. Cameron will therefore be looking more for a Boris "bounce" than a failure. Johnson needs to take this into account and perform the acrobatic trick of refraining from overstating his disagreements with central government merely to emphasise his interest in London rather than national politics ${ }^{40}$. Livingstone was in much the same situation in the run-up to the 2004 election when New Labour was low in the opinion polls, but contrary to Johnson, he had a history of contradicting his own party when his convictions dictated he had to ${ }^{41}$.

In May 2012, just like Livingstone in 2008, Johnson will have a record to defend. He won't be able to treat the mayoral election as some big joke that will enable him to guffaw his way to a second victory and be present on the evening of $27^{\text {th }}$ July $27^{\text {th }}$ to open the Olympic Games. Johnson's record is honourable but far less revolutionary than his predecessor's and indeed many of his projects were initiated by Livingstone $^{42}$. Even so, the GLA precept has been frozen, the Olympic budget brought under control, likewise the western extension of the congestion charge. His gaffes have been few and far between but his declaration that the $£_{250,000}$ a year he receives from the Daily Telegraph for a weekly column is "chickenfeed" has provided ammunition for his opponents to chip away at his credibility as a "Tory toff' out of tune with Londoners.

\footnotetext{
${ }^{40}$ In June 2011, in an act of brazen defiance, Johnson publicly stated that Greece had gone bust and should withdraw from the eurozone. In the same vein, he also opposed Kenneth Clarke's plans to soften sentencing laws.

${ }^{41}$ Whitton T., op. cit., p. 131-132.

${ }^{42}$ Barclay's Cycle Hire is a perfect example. The bicycles are commonly referred to as "Boris Bikes" even though Livingstone drew up the initial plans to introduce a bicycle sharing system based on the Parisian "Vélib" model. For information concerning the scheme see http://www.tfl.gov.uk/roadusers/cycling/14808.aspx .
} 
This leaves essentially the Olympic Games which generally speaking are going to plan to the extent that on an inspection visit to mark the milestone of "one year to go", Jacques Rogge, president of the International Olympic Committee declared that "Preparations are excellent. They are on time, on budget. Quality-wise we have not the slightest concern. There is no doubt about that. London is very well organised, the team is very strong. We are very optimistic" ${ }^{\prime 3}$. This must have been music to the ears of Johnson who knows full well that the final competition will be between himself and Livingstone, with one other candidate perhaps topping $10 \%$ of the first count ${ }^{44}$.

Johnson can rely on Olympic success to boost his candidacy but be must beware of coming across as his party's stooge. Cameron and Osborne can expect a certain degree of solidarity, especially when the going gets tough: in May 2008 Labour were behind in the national polls and Johnson reaped substantial advantage from this. In 2012, the situation could be the reverse with Johnson suffering from his political allegiance with an unpopular coalition and Livingstone gleaning the extra votes that had failed to give him a third term in the last election. There will be political renewal in May, either for Johnson, who could reinforce his powerbase and popularity in order for Downing Street to be a distinct possibility, or for Livingstone, who will demonstrate his limpet like ability to win elections, often in the familiar face of considerable adversity.

43 "Olympic Games: IOC leader lauds London as 2012 preparations enter final straight: Countdown to London 2012: Rogge says progress is the best he's seen but fears influence of illegal betting", The Guardian, 26/07/2012.

${ }^{44}$ Brian Paddick for the Liberal Democrats, will most certainly be the third man once again. 


\section{Bibliography}

Carvel, J., Turn Again Livingstone, London, Profile Books, 1999.

Conservative Party manifestos, 2001, 2005 \& 2010.

D'Arcy, M., \& Maclean, R., Nightmare: the race to become London's Mayor, London, Politico's Publishing, 2000.

Edwards, G., \& Isaby, J., Boris v. Ken: how Boris Johnson won London, London, Politico's, 2008.

Forrester, A., Lansley, S., \& Pauley, R., Beyond our Ken, a Guide to the battle for London, London, Fourth Estate Ltd, 1985.

Gimson, A., Boris: the rise of Boris Johnson, London, Simon \& Schuster, 2008.

Hansard.

Hosken, A., The Ups and Downs of Ken Livingstone, London, Arcadia Books, 2008.

http://www.london.gov.uk

http://www.londonelects.org.uk

http://www.london.gov.uk/gla/publications/factsandfigures/londonelections-may08.rtf

Labour Party manifestos 2001, 2005 \& 2010.

Liberal Democrats, manifestos, 2001, 2005 \& 2010.

Livingstone, K., If Voting Changed Anything, They'd Abolish It, London, Harper-Collins, 1987.

Pilkington, C., Devolution in Britain Today, Manchester, Manchester University Press, 2002.

Pimlott, B., \& Rao, N., Governing London: Recreating the Metropolitan Community, Oxford, Oxford University Press, 2002.

Whitton, T., Ken « le rouge » et la Mairie de Londres. Du Greater London Council à la Greater London Authority, Paris, l'Harmattan, 2010. 